\title{
Economic Journalism as a Modern Educational Trend
}

\author{
Natalia I. Zykun, Olena P. Kalyta, Ihor Koziura
}

\begin{abstract}
The article deals with peculiarities of the process of training economic journalists in the context of contemporary educational challenges and trends. On the basis of generalization of modern Ukrainian media practices, systematization and interpretation of scientific researches, related to the topic of the article, analysis of educational programs and curricula of institutions of higher education, the authors argue the justification and expediency of the specialization "economic journalism" on the problem-thematic principle.

The content of the concept 'economic journalism' is defined in terms of functional purposefulness, attention is focused on its expressive analyticity. The tasks of the economic segment of Ukrainian journalism are formulated under conditions of deepening democratization processes and development of civil society.

The disadvantages of this segment of media discourse are determined (focus on narrow audience, superficiality and unprofessional performance of the coverage of economic issues, selectivity, fragmentation of the media picture of the economic sphere of social activity, etc.). The topicality of specialized training of economic journalists, in particular - and in combination with other subject areas - is emphasized. Content components of economic journalists training is defined as a combination of actual journalistic and economic blocks of knowledge and the involvement of data on processes in related social sectors. Methodological principles, such as: practical orientation, integration nature, use of interactive teaching methods, design technology; effective forms of organization of the process of training journalists of economic specialization (e.g. master classes, different types of practice); work on complex creative projects (television, radio, press, internet, photo projects, etc.) are formulated.
\end{abstract}

Keywords : journalistic specialization, problem-thematic specialization of a journalist, economic journalism, journalistic education, project activity.

\section{INTRODUCTION}

Professional journalism education is constantly in the process of seeking the most optimal standards and tools to train professionals for media activity. The logical needs for facing the change in the areas of activity displayed by media, a

Revised Manuscript Received on November 15, 2019

* Correspondence Author

Natalia I. Zykun D.Sc. (Social Communication), Associate Professor, Head of Department of Journalism, Ukrainian Literature and Culture, University of State Fiscal Service of Ukraine

Olena P. Kalyta Candidate of Pedagogic Sciences, Associate Professor, Department of Journalism, Ukrainian Literature and Culture, University of State Fiscal Service of Ukraine

Ihor Koziura Professor of the Department of Management, Doctor of Public Administration, Poltava University of Economics and Trade, Ukraine *Corresponding author:

Email: nzykun@ukr.net, Tel. +38-0992222310 transformation of the information space in modern conditions are complemented by the inevitability of taking into account globalization processes in the context of the desire to preserve national peculiarities and benefits in professional training. The issues of approaches to journalistic education, formation of basic professional competencies, and mastering the media skills were covered by Ukrainian (V. Zdoroveha, I. Mikhailin, V. Rizun, V. Shklyar) and foreign authors (V. Berezin, V. Bolotov, V. Voroshilov, V. Gorokhov, Y. Zasursky, S. Korkonosenko, O. Korochensky, S. Raspopova, and others).

The problem of professionalism of media employees and the quality of contemporary media texts also generates heated social discussions. Taking into account the complex organization of the modern world as an object of media activity, the issue of universalism and the specialization of the journalistic profession is of particular importance. The journalistic environment recognizes specialization on various grounds: 1) by the form of media (tele-journalism, radio journalism, the press, electronic editions); 2) by genre preferences (reviewers, commentators, essayists, etc.); 3 ) by the subject area (economic, sports, political, etc.). In business journalism, first of all, such arrays of information as economic, political, technical, spiritual, military, cultural and artistic, scientific, etc., which are most relevant to the basic social problems, and therefore - the interest and expectations of the audience, are distinguished. Feasibility of subject-thematic specialization [7, p. 2] is based on this ground.

We consider economic journalism a major subject-thematic (or otherwise - problem-thematic) specialization, which nowadays is becoming increasingly popular among the applicants of higher education. The task of determining the peculiarities of economic journalism as an educational direction, its main tasks and methodical tools is currently extremely important.

\section{MATERIALS AND METHODS}

\subsection{Materials}

The data for formulating generalizations by the authors were provided by a review of the practice of training economic journalists in post-Soviet countries and Eastern Europe; systematization and interpretation of scientific research devoted to this problem; studying the results of the public discussion on the standards of journalism in Ukraine in the context of global trends. The authors analyze educational programs for training journalists, curricula of a number of Ukrainian journalist institutions of higher education, curricula of certain university disciplines, which are taught to future journalists, in order to distinguish the important professional competencies which are to be formed.

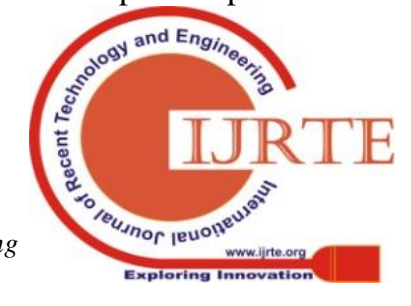




\subsection{Methods}

In the analysis of selected educational and professional sources, the following general scientific methods, such as content analysis, were used to determine problem-thematic dominant in professional theory. Analysis method and narrative method contributed to penetration into the essence of journalistic economic specialization as a complex of general and professional competencies; determination of specificity of the dual nature of professional training of an economic journalist: as a carrier of basic journalistic knowledge and skills, and the carrier of economic information. Methods of synthesis and generalization are the basis for the formulation of conclusions, definition of content, methodological features of economic journalist education.

\section{RESULTS}

The justification and expediency of specialization 'economic journalism' on the problem-thematic principle has been proven at the end of research.

The content of the concept 'economic journalism' is defined in terms of functional focusing, attention is drawn to its expressive analyticity.

The task of the economic segment of Ukrainian journalism is formulated under conditions of deepening democratization processes and development of the civil society.

The content components of the integrated educational program for the economic journalists training are defined, namely, journalistic and economic ones.

The methodological principles (practical orientation, integrated character, use of interactive teaching methods, design technology) are systematized, effective forms of organization of the process of training of journalists of economic specialization (master classes, various types of practice, work on complex creative projects) are determined. Under modern conditions, not only the fact becomes important, but the position, the readiness of the author to offer a chain of interrelated facts, actions and consequences. In the context of general function of the journalistic profession, which is to seek, produce, collect and disseminate information, the authors define economic journalism as 'the search, analysis and presentation of information about the economy' [4, p. 15]. Despite the recognition of the supply an operational economic information to the audience as one of the functions of economic journalism, the priority is given to its analytical and predictive component: economic journalism, as V. Voroshilov [2] emphasizes, forms a complete and consistent picture of the modern world based on: analysis of the main events in the country, clarification of their impact on business life; broadcast of the most important international economic news; research of social problems that accompany economic changes in society. Among its tasks, according to the scientist, is spreading economic experience; expansion of business horizons; analysis of the impact of economic information on the economy; formation of the business ideology.

However, this analysis has an independent information value, which is based on the use and synthesis of a solid array of reliable data and facts. Thus, practical economic journalism, as recognized by the authors, ceases to be an instrument of ideological influence, it has become a "component of the market economy infrastructure" [9].

The authors acknowledge such an interpretive and educational role of economic journalism as 'selection, adaptation and reporting to the audience the information, the sources of which are specialized economic journals, reference books,' 'dissemination of economic information produced by research and development institutions of strategic development and forecasting, consulting groups, agencies and experts' [1, p. 2].

Despite a certain slippage of economic reforms and development of the economic sphere in Ukraine, aimed at actualizing the economic media projects, the demand for economic materials in the media is growing every year. The value of economic knowledge for the modern educated consumer of media production in an era of domination of globalization trends is determined by a number of factors:

1) economic literacy of the population is one of the conditions for the formation of the civil society, the basis for democratization of social processes;

2) awareness of economic realities increases the criticality of media audiences' thinking, its objectivity in evaluating social realities;

3) knowledge of the main economic mechanisms and principles facilitates the control of government activities and the efficiency of spending state funds by citizens as taxpayers;

4) understanding of economic processes lies at the basis of forming the responsibility of citizens as an audience of economic journalism;

5) economic media publications help readers / viewers / listeners to make their own economic decisions or avoid unwanted economic consequences, both by business representatives and ordinary citizens;

6) media discussions on economic problems form the economic policy to some extent, as pointed out by [8], 'economic news affects economic expectations and behavior of the population.'

An analysis of Ukrainian media discourse gives grounds for formulating some disappointing conclusions about its economic segment, which is confirmed by other media reviews. Among them, the first thing to note is the lacuna in niche of economic specialized publications. The authors point out that the demand today far exceeds the offer: 'There is no daily business newspaper or TV channel, magazine or business radio. There are several business publications - the Dengi, the Delovaya Stolitsa, Delo.ua, as well as several niche editions, for example, for agrarians or accountants, and a dozen business departments in the editorial boards of large media' [8]. Economic realities, within the limits of their concepts and tasks, are reflected mainly by national political and social media. Private editions have special economic departments, such as the information and analytical weekly the Dzerkalo Tyzhnia.

The shortcomings of the modern segment of economic journalism, based on the generalization of Ukrainian practice, include:

1) a kind of "closeness", an orientation towards a narrow, prepared audience of authors of specialized publications;

2) misusage of a large amount of digital data, special terminology and other, not clear to the general public, as well as formats of information and publications of general content; 
3) superficiality and unprofessional reflection of economic realities;

4) bias, ideological preconception of individual materials and assessments;

5) selectivity of the displayed economic facts, realities and events, and hence the fragmentation of the media picture of the economic segment of social activity, the removal of ambiguous and regional events and contexts from it.

All this update the approach to training journalists in Ukrainian Higher Educational Establishments. Special journalism education, particularly in high school, is relatively young on the background of other subject areas. However, its contents, format, duration, methods of educational activity are being actively discussed - both by practicing journalists, and in academic and scientific circles [10]. Moreover, contradictions in their positions are kept virtually in all of the above-mentioned points.

J. Pulitzer, who holds an initiative to introduce a systematic professional training for journalists, recognizing natural abilities as the key to success in each industry, argued for the need of special and general training [Cited by 7].

The next important step was the selection of material that is compulsory for assimilation and awareness by future media workers, which is constantly changing due to educational trends. Thus, at one time, a re-orientation from the philological aspect of journalistic training (which dominated the Soviet era) to the social communication one, was made in Ukraine.

At present, we can observe a tendency to integrate knowledge, in particular, in the process of training journalists. And despite the fact that media structures value universal journalists who are ready to work on various media platforms, with different genre concepts and promptly issue "variegated" research, we are convinced that universality is achievable in modern conditions, in the form of media and genre preferences.

For a subject-thematic factor, certain reservations should be formulated. Nowadays, a prerequisite for a successful journalist who is ready to broadcast costly observations, to provide original and weighty comments, the one who has his own audience, is the deep awareness of the topic. A modern journalist is largely an expert in the research problem. This was noticed by managers of higher education, therefore, such educational journalistic programs, which envisage an organic combination of instrumental and journalistic training, with subject matter, in our case, economic, are becoming widespread. We should recognize that we are taking the first steps while American and European universities offer students a range of educational economic journalism programs: business journalism, financial journalism, global business journalism, and economic investigations, entrepreneur journalism, business Journalism [8]. In European higher education, journalism is taught together with a different, usually basic, specialization: in the Economic University of Bratislava (Slovakia), you can receive a degree in Economics and Economic Journalism [6]; in the Humanities and Economics Academy (Akademia humanistyczno-ekonomiczna) (Lodz, Poland) - 'Political marketing with elements of journalism' (Master's degree) [3]; at the Economics University in Poznan (Poland) - 'Economic Journalism and Public Relations' (undergraduate, postgraduate) [11] and others.
Due to the lack of a broad proposal of economic journalistic specialization in Ukrainian universities (with a few exceptions, such as a course on the basics of economic journalism in the Mohyla School of Journalism, economic specialization at the Institute of Journalism of the Taras Shevchenko National University; specialization in Economic Journalism is since recently offered by the Institute of Design, Architecture and Journalism (Kyiv), informal journalistic training is gaining in popularity: the Center for the Improvement of Economic Journalism at the Kyiv School of Economics, which sees its mission in 'raising the level of economic debate and financial literacy of the population directly affecting the quality of the decisions that are being made,' trains journalists within the School of Economic Journalism. It was created together with VoxUkraine, Visa and ICU with the support of Nova Poshta [12]. As we see, it is logical to study economic journalism in the educational institutions where the main specialization is journalism. Since 2017, training of journalists is also conducted at the University of State Fiscal Service of Ukraine with the orientation to the master's program in economic journalism.

Practitioners recognize the expediency of searching for a "balance between economics, politics and humanitarian aspects" [9] in order to "reconcile" the expectations of all parties to such media communications.

Recognizing the wide range of functions of economic journalism and the importance of its tasks, we believe that educational activities aimed at training economic journalists have a set of features: both of the content and the methodological nature. The first is to clearly distinguish between two subject blocks: journalistic and economic ones, with the involvement of data on processes in adjacent social sectors. An economic journalist should be qualified to communicate information on complex economic issues in an accessible form to the general public. It requires the formation of his analytical skills, critical thinking; knowledge of the laws of the development of the economic sphere (budget and budget expenditures, tax principles, exchange rates, stock market, bank lending portfolios, business and entrepreneurship, market, price formation in a market economy, interest and dividends, import-export, monopoly, competition, offshore systems, money laundering, raider attacks, etc.); possession of a methodology for analyzing economic phenomena and processes; operation of digital data, statistical information; ability to work with sources of information, interact with newsmakers, press services. A survey of representatives of the Ukrainian media of general content (not specialized) on the need for the subject of economic knowledge they had to face, gave grounds for formulating the following directions: a workshop on the budget of the region/district/city of regional and district importance for journalists; principles of forming the revenue and expenditure parts of the budget; protected budget articles (how are they being formed and spent); development budget; attraction of extra-budgetary funds by local budgets on target programs; the principles / formulas for calculating state subventions and subsidies, the actual difference between subvention and subsidy (for many people confuse these concepts); sequestration, expediency of its use, etc. Today, the Ukrainian reader's steady interest in such segments of public life as financial and economic, including taxation,

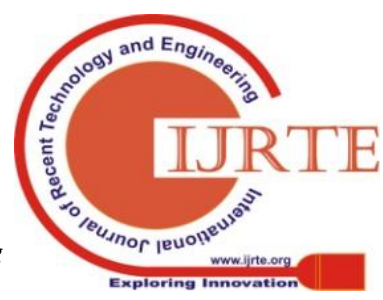


audit, financial investigations, customs, has been formed. Formation of an information field on the activities of tax authorities, the introduction of effective tools for their communicating with citizens and business, a radical change in the attitude of the population towards the activities of fiscal workers is actual for Ukraine.

Speaking about the methodological principles and methodical tools, it is worth pointing out such features as: the clearly practical orientation of economic journalists training; integrational character; use of interactive teaching methods; widespread use of design technology.

Today, master classes, different types of practices, work on complex creative projects (television, radio, press, internet projects, photo projects, etc.) belong to effective forms of organization of educational process.

At the heart of the design technology of learning are the ideas of J. Dewey, V. Kilpatrick, E. Thorndike. This method can be described as 'learning through actions,' when the learner is involved in an active cognitive process: independently formulates the problem, collects the necessary information, finds and compares the options for solving the problem, makes conclusions, analyzes its activities, forming 'brick by bricks' something new and gaining new educational and life experience.

Technological concept of design technology focuses on the way of obtaining new knowledge in specific conditions and their use in practice, which determines the specifics of the project activity of future journalists. These formats include internships and one-time creative tasks in collaboration with local news agencies, TV channels and newspapers. The project technology involves the implementation of a system of didactic tools (content, stages, methods, etc.), modeling problem situations that require students to search, research efforts aimed at finding effective ways to solve problems, their public presentation and analysis of the results. Therefore, it is developing environment, which forms professional competence in future specialists, promotes acquisition of educational, professional and life experience.

Such an approach is especially relevant nowadays and with respect to the importance of dual education in Ukraine, in the context of which it becomes possible to combine the benefits of the educational and manufacturing spheres in the training of modern staff [5]. This is entirely justified in the educational process of training economic journalists where a cooperation with media production, the involvement of economists and other professionals in the educational process is practiced.

\section{CONCLUSION}

Consequently, economic journalism can be characterized as a modern educational trend, the bases of which are the content and methodological and methodological features, aimed at forming the readiness of future media professionals to work in a fast-changing world.

Among the decisive components of an integrated educational program for training of economic journalists is journalism and economics. The main methodological principles of the process of training economic journalists are its practical orientation; integrational character; use of interactive teaching methods; design technology.

According to the authors, the following methods: master classes, different types of practices, preparation of complex creative projects (television, radio, press, Internet projects, photo projects, etc.) have the main effect on organizing the process of training journalists for economic specialization.

\section{REFERENCES}

1. Burkivska, L., Romanishin, Y. (2014). Economic topics in the Ukrainian regional media space. Visnyk Knyzhkovoi Palaty [Bulletin of the Book Chamber]. Vol. 2. Pp. 1-3.

2. Voroshilov, V. (2006). Teoriya i praktika massovoj informacii: uchebnik [Theory and practice of mass information: textbook]. St. Petersburg: Publisher Mikhailov VA.

3. Humanities and Economics Academy (Akademia humanistyczno-ekonomiczna).

http://www.unekostudy.com/index.php/2015-02-17-14-59-24/2015-0 2-17-15-00-23/humanitarno-ekonomichna-akademiia-lodz

4. Dobretsova, N.N. (ed.) (2009). Osveshhenie jekonomicheskih tem v stedstvah massovoj informacii (jekonomicheskaja zhurnalistika): ucheb. posobie dlja vuzov [Coverage of Economic Themes in Means of Mass Media: Textbook]. Bishkek: Printhouse.

5. Dualna osvita [Dual education] / Ministry of Education and Science of Ukraine.

https://mon.gov.ua/ua/osvita/profesijno-tehnichna-osvita/dualna-osvit a

6. Zdoroveha, V. (2000). Pidgotovka zhurnalistiv: poglyad zboku $i$ zseredini [Training Journalists: Views from Outside and Inside] / Dzerkalo tyzhnia. http://old.gazeta.dt.ua/EDUCATION/pidgotovka_zhurnalistiv_poglya di_zboku_i_zseredini.html

7. University of Economics in Bratislava. https://simplex.ua〉Higher education abroad`Slovakia

8. Kryuch M. (2017) Komu potribna ekonomichna zhurnalistika v Ukraini? [Who needs economic journalism in Ukraine?]. https://ms.detector.media/ authors_view/komu_potribna_ekonomichna_zhurnalistika_v_ukraini /

9. Lavrinikevich, D. (2015). Kak osveshhat' sobytija v jekonomike cherez «prostyh» ljudej [How to Highlight Events in Economics through "Average" People]. http://mediakritika.by/article/2958/kak-osveshchat-sobytiya-v-ekono mike-cherez-prostyh-lyudey

10. Report on the International Conference "Economic Journalism as a Factor and Indicator of the Marker Economy Development" (Bishkek, 11-12 October 2012). dpi.kg/upload/file/ Full_Report_Bishkek_Conference_2012_RUS.pdf

11. 11.Uniwersytet Ekonomiczny w Poznaniu. https://ue.poznan.pl/pl/

12. Tsentr udoskonalennia ekonomichnoi zhurnalistyky [Center for the Improvement of Economic Journalism]. https: //ceej.kse.ua/

\section{AUTHORS PROFILE}

Natalia I. Zykun D.Sc. (Social Communication), Associate Professor, Head of Department of Journalism, Ukrainian Literature and Culture, University of State Fiscal Service of Ukraine

Olena P. Kalyta Candidate of Pedagogic Sciences, Associate Professor, Department of Journalism, Ukrainian Literature and Culture, University of State Fiscal Service of Ukraine

Ihor Koziura Professor of the Department of Management, Doctor of Public Administration, Poltava University of Economics and Trade, Ukraine *Corresponding author: Email: nzykun@ukr.net, Tel. +38-0992222310 